\title{
H-Hope Plus Kinesthetic With VCO On Weight And Body Length Of Preterm Infants
}

\author{
Lia Dian Ayuningrum \\ Alma Ata of University \\ Email: lia.liadianayuningrum@gmail.com
}

\begin{abstract}
Abstrak
Prematuritas masih menjadi masalah kesehatan utama di Dunia. Bayi premature dengan berat badan lahir rendah sangat beresiko terhadap keterlambatan perkembangan pertumbuhan, terutama berat badan. Komplikasi Prematuritas pada tahun pertama menyumbangkan 1 juta anak meninggal dan setiap tahun sekitar 15 juta bayi lahir premature. Salah satu intervensi yang dapat diberikan adalah visual- tactile-kinesthetic stimulation. Stimulasi adalah salah satu stimulus yang meningkatkan pengalaman sensorik dan motoric yang menyebabkan bayi premature mengalami kemajuan dalam hal pertumbuhannya. Penelitian ini untuk menjelaskan efektifitas H-Hope plus Kinesthetic dengan VCO terhadap berat badan dan panjnag badan bayi premature. Penelitian ini menggunakan jenis eksperimental design dengan pretest-posttest yang menggunakan control group design. Variabel terikat dalam penelitian ini adalah $\mathrm{H}$-Hope plus Kinesthetic dengan VCO dan Kangaroo Mother Care (KMC). Sampel pada penelitian ini adalah bayi premature post Hospital-Care. Teknik sampel menggunakan probability sampling dengan random sampling. Penelitian ini menggunakan 30 responden dengan 15 orang disetiap kelompok intervensi dan kelompok control. Hasil dari intervensi H-Hope plus Kinesthetic dengan VCO yang dilakukan selama 14 hari adalah intervensi ini dapat meningkatkan berat badan dan panjang badan dengan nilai signifikan $p=0.001$ dan $p=0.009$. H-Hope plus kinesthetic dengan VCO terbukti lebih efektif dalam meningkatkan berat badan dan panjang badan bayi premature.
\end{abstract}

Kata Kunci : H-Hope, Preterm, Berat \& Panjang.

\begin{abstract}
Prematurity is still a major health problem worldwide. Premature babies with LBW are at risk of developing growth disorders, especially body weight. Prematurity complications in the first year contribute to one million children die and each year around 15 million babies are born prematurely. One intervention that can be given is visual-tactile-kinesthetic stimulation. This stimulation is a stimulus series that provides sensory and motor experiences so that premature babies can show their appropriate growth progress. This research to determine the effectiveness of H-HOPE plus kinesthetic with VCO on the weight and body length of preterm infants. This type of experimental design study with pretest-posttest with control group design with independent variables was intervention in the form of H-HOPE plus Kinesthetic with VCO and Kangaroo Mother Care (KMC). The samples in this study were preterm infants post Hospital-Care. Sampling used probability sampling technique with random sampling. The number of samples in this study is 30 respondents with 15 people in the intervention and control groups. The results of giving H-Hope plus kinesthetic with VCO interventions for 14 days in increasing weight and body length obtained sig value of 0.001 and $0.009 \mathrm{H}$-Hope plus kinesthetic with VCO is more effective in increasing weight and body length.
\end{abstract}

Keywords: H-Hope, Preterm, Weight \& Length 
Article info:

Article submitted on September 26, 2018

Articles revised on October 24, 2018

Articles received on November 22, 2018

DOI: $h$ ttp://dx.doi.org/10.21927/jnki.2018.6(3).226-231

\section{INTRODUCTION}

In Indonesia, it is mentioned that it is estimated that babies are born around 350,000 premature babies or low birth weight. The pattern of causes of death showed that the proportion of causes of neonatal death in the highest 0-7 day age group was premature and low birth weight, then asphyxia was born. Percentage of Low Birth Weight Babies in Central Java each year tends to increase by $3.73 \%$ (2011), 3.90\% (2014), 5.1\% (2015) (1). Premature babies more easily lose skin stimulation that occurs in the intrauterine phase through skin contact with amniotic fluid and the mother's uterine wall. This condition is one of the determining factors in the growth and development of the baby's nerves (2). In addition to the initial sensory deficiencies, prematurity causes other related factors, such as the absence of bonding between the mother and newborn baby due to the need to last in the unit Neonatal intensive care (NICU), which has an adverse effect on the psychological and biological (3) development of children and parental well-being (4).

Babies born with a body weight of less than 2500 grams are twenty times more likely to experience death in the first month of life compared to babies born with normal weight. This risk increases higher in infants with birth weight less than 1500 grams. The rate of growth of premature babies in the first year is generally lower than that of term infants born on the same day. Deficits in these growth rates tend to correspond to the level of prematurity. Nutritional problems are one of several serious problems in premature babies. Babies born prematurely have an immature digestive system that can cause problems, especially in foods that need special handling. This disorder occurs because infants with low birth weight (LBW), only have a small subcutaneous fat deposits, limited reserves of brown fat, and suction reflexes and swallow the weak baby.

There are some babies weighting $<2500$ grams can be discharged because of the stable condition. The high cost of care is one of the family's factors to speed up the time to care for premature babies at the hospital and choose to take it home. The problem is that baby care at home will not be the same as the procedure performed in the hospital. Meeting the physical needs of premature babies at home is to maintain a normal body temperature, intake of breast milk so that the baby reaches normal weight and prevention of infection. According to research, states that mothers who care for premature babies at home tend to feel unsure and anxious when they start interacting with their babies (5).

The growth system of premature babies will experience a decrease in the first week, namely weight loss around $10-15 \%$ of birth weight and is expected to experience an increase in body weight in the second week of $15 \mathrm{grams} / \mathrm{kg} /$ days until it reaches a normal weight of 2500 gram and $0,8-1 \mathrm{~cm} /$ weeks for increase of body lenght (6). The development of science and technology raises new innovations, especially in an effort to improve the welfare of premature babies with various interventions for growth and development. The recommendation that has been applied is Kangaroo Mother Care/KMC method with skin to skin to maintain the baby's temperature through the skin of his mother. 
Extrauterine growth of premature babies can also be stimulated by tactile, kinesthetic, vestibular, oral, auditory stimulation and other stimulation combinations. Stimulation given over time can also help the baby adapted to the extrauterine environment (7).

The study of the mechanism of the effects of infant massage on physiological and biochemical changes to promote growth, including increased vagus activity which in turn affects the release of digestive hormones such as gastrin, insulin and insulin-growth factor (IGF-1) and increases the efficiency of the body's metabolic processes. Another effect of massage therapy is to reduce stress levels in infants as evidenced by decreased cortisol levels in infants, thereby increasing the quantity of baby sleep and increasing maternal and child bonding. Research conducted by White et al, which examined the effect of H-HOPE interventions on preterm infants proving faster body weight development compared to groups that were not given the intervention (8).

Research conducted by Field, et al proved that premature babies who are massaged will experience greater weight gain (47\%) (9). In other research stated that low birth weight babies who were massaged using sunflower seed oil for 14 day, experienced an increase in body weight of around 249 grams (10). Research stated that newborns who were given massage with coconut oil (coconut oil), increased their body weight more than using mineral oil. Another study Stated that babies who were massaged with MCFA-containing oils had greater weight gain (11). Sumawidayanti et al, stated that infants who were given Mozart classical music therapy experienced an increase in body weight during the perinatology room. Kangaroo Mother Care method was carried out for 3 weeks this method not only stabilized the temperature but also increased body weight by around 504gr (12).

Based on the description above, that the more complications experienced by premature babies, so that more and more innovation is needed to be done, so that the welfare of premature babies can be maximized, researchers are interested in conducting research entitled "H-HOPE plus kinesthetic with VCO on weight and body length in preterm infants.

\section{MATERIALS AND METHODS}

This study used a quantitative approach with Experimental Design method. The samples in this study were preterm infants post- Hospital care. The sampling technique uses probability sampling technique with random sampling. Data collection techniques were carried out by participant observation and questionnaire distribution. The collected data was then analyzed using univariate and bivariate analysis techniques. The hypothesis is there are differences in weight and body length in premature babies after being given H-HOPE plus Kinesthetic with VCO.

\section{RESULT AND DISCUSSION}

Based on table 1. can be explained that in both groups experienced a weight increase that was in accordance with the standard weight gain at low birth weight that is $15 \mathrm{grams} / \mathrm{kg} /$ day. In the $\mathrm{H}$-Hope plus kinesthetic group with VCO and $\mathrm{KMC}$, the average post-test score was higher than the pre-test score with a body weight $>2500$ grams, which represented a normal baby's weight with a difference of 612.27 grams which means

Table 1. Descriptive Analysis Of Body Weight On Premature Infants

\begin{tabular}{cccccc}
\hline \multirow{2}{*}{ Variabel } & \multicolumn{2}{c}{ Groups } \\
\cline { 2 - 5 } & \multicolumn{2}{c}{ Intervention } & \multicolumn{2}{c}{ Control } \\
\cline { 2 - 5 } & & Mean \pm SD & Min-Max & Mean $\pm S D$ & Min-Max \\
\hline Body weight & Pre & $2080 \pm 292.57$ & $1495-2500$ & $2019.33 \pm 75.04$ & $1905-2150$ \\
& Post & $2694 \pm 275.94$ & $2105-3105$ & $2290.13 \pm 61.87$ & $2205-2385$ \\
\hline
\end{tabular}


Table 2. Differences In Body Weight In The Intervention Group And Control

\begin{tabular}{llllcc}
\hline Variable & Groups & Mean Rank & Sum of Ranks & $\mathbf{Z}$ & $\boldsymbol{P}$-value \\
\hline Body Weight & Intervention & 23.00 & 345.00 & -4.670 & 0.001 \\
& Control & 8.00 & 120.00 & & \\
\hline
\end{tabular}

*Mann-Whitney test

Table 3. Descriptive Analysis Of Body Length On Premature Infants

\begin{tabular}{|c|c|c|c|c|c|c|}
\hline \multirow{3}{*}{\multicolumn{2}{|c|}{ Variabel }} & \multicolumn{4}{|c|}{ Groups } & \multirow{3}{*}{ P-value } \\
\hline & & \multicolumn{2}{|c|}{ Intervention } & \multicolumn{2}{|l|}{ Control } & \\
\hline & & Mean士SD & Min-Max & Mean $\pm S D$ & Min-Max & \\
\hline \multirow[t]{2}{*}{ Body length } & Pre & $41,06 \pm 4.19$ & $32-45$ & $39.56 \pm 0,72$ & $38-41$ & 0.009 \\
\hline & Post & $42.80 \pm 3.85$ & $34-46$ & $40.37 \pm 0,67$ & $39-42$ & \\
\hline
\end{tabular}

intervention given effective increase weight to $45.7 \%$ for 14 days. However, in the control group even though there was an increase, the mean value of the post-test did not reach the normal body weight of $<2500 \mathrm{gram}$.

Based on table 2. can be explained that the Mann-Whitney test showed that $\mathrm{H}$-Hope plus kinesthetic with VCO were more effective in increasing body weight in preterm infants compared to the control group given the KMC method with $z$-values and $p$-values of -4.670 and 0.001 , respectively <0.05).

Based on table 3. can be explained that in both groups experienced a length increase that was in accordance with the standard weight gain at low birth weight that is $0.8-1 \mathrm{~cm} /$ weekes. In the $\mathrm{H}$-Hope plus kinesthetic group with VCO and $\mathrm{KMC}$, the average post-test score was higher than the pre-test score with a body length and more effective in increasing body length with p-value $0.009(<0.05)$.

In this study, an evaluation or growth measurement covering weight and body length for 14 days was carried out. The results of the study based on intervention for 14 days showed an average weight gain of 612.27 grams. The increase in the mean value on the variable is supported by effect size analyze amounted to 2.0 (high value). This result showed that $\mathrm{H}$-HOPE plus kinesthetic with VCO better than a massage with MCT that has an effect size value 0.1 or with the tactile kinesthetic stimulation that effect size value is 0.5 . Statistical test results using the Wilcoxon test showed that in the intervention group there was a significant difference that illustrated the increase in body weight with $p=$ $0.001(p>0.05)$. This research is in line with that carried out by Rosemary et al., The results of which infants were given $\mathrm{H}-\mathrm{HOPE}$ interventions (audio, tactile, visual and vestibular) gained weight faster with a mean difference of 46.3 grams compared to the control group (13). In this study based on the culture of the respondents, researchers adopted audio, tactile, visual and kinesthetic implementation procedures with premature massage (14). The research conducted by Sankaranarayanan et al., Which resulted in babies being massaged using VCO had a greater body weight with a difference of 162.39 grams compared to groups using mineral oil (9). Saeidi et al., In his study also concluded that massage babies using oil containing MCFA increases body weight by 105 grams compared to those massaged without oil.(15)

In this study, the expected results of weight gain for 14 days were 420-490 grams, while the average difference in body weight obtained was 612.27 grams. The results of these improvements can be achieved due to the intervention is given in the form of a combination of H-HOPE plus kinesthetic with VCO and KMC method in the intervention period for 14 days. Body weight is 
the result of an increase or decrease in all tissues that exist in the body, such as bones, muscles, fat, body fluids and others that can be used as an indicator to determine the baby's growth and development through weight gain. Nutritional intake or exclusive breastfeeding for infants aged 0-6 months is a direct factor that most influences the baby's body weight. In this study, researchers controlled by including respondents who were only breastfeed.

Assessment of growth not only increases weight, but also increases body length. Body length is used as a standard for assessing nutritional status or a good indicator for infant growth. 58 The results of the study based on interventions for 14 days showed a mean increase in body length of $1.73 \mathrm{~cm}$ which means $\mathrm{H}$-Hope plus kinesthetic with VCO can increase body length by $0.8 \mathrm{~cm} /$ week and increase in body length within the normal limits of the standard for adding body length to premature babies for 14 days, namely $1.6-2.0 \mathrm{~cm}$. 16 The effect size analysis of this study was 0.8 with a high category, this shows that the effect size of H-HOPE plus kinesthetic with VCO is better than infant massage with oil which has an effect size 0.1 . The increase in mean value is supported by the effect size value of the ice value $=0.8$ (high). These results indicate that the H-HOPE plus kinesthetic intervention with VCO has a high influence value at the cohen test. Whereas in the control group given the KMC method there was an increase in body length of $1.12 \mathrm{~cm}$ which means that if converted in units of days can increase the body length by about $0.56 \mathrm{~cm}$ per week. The increase of $1.12 \mathrm{~cm}$ in the control group has not reached the expected normal limit of $1.6-2 \mathrm{~cm}$.

$\mathrm{H}$-Hope plus Kinesthetic with VCO promotes growth hormone for somatomedin release, which is the growth factor secreted most by the liver. One of the main somatomedin contained in the blood is IGf-1, a growth hormone that affects the growth of various body tissues (16). This study is in line with what was done by Rosemary et al., The results of which infants given H-HOPE intervention experienced a faster increase in body length compared to the control group. ( $p$ $=0.001)$. Other studies that tested oil massage with oil for 28 days in very low-proof birth weight infants could increase body length that interventions can increase body length by 0.6 $\mathrm{cm} /$ week $(p=0.001)(8)$.

\section{CONCLUSION AND RECOMMENDATION}

The H-Hope plus Kinesthetic method with VCO given to premature infants after hospital care gives the effect of increasing weight and body length-. H-HOPE plus kinesthetic intervention with VCO which is integrated with parental participation which in this case the mother-baby is proven to support exclusive breastfeeding and interactions that form stronger bonding.

The results of this study indicate that the $\mathrm{H}$-Hope plus kinesthetic method with VCO can be used as an alternative treatment for premature babies at the NICU and for post-treatment at the Hospital. The integrity of the implementation of the intervention with the mother of the baby, is expected to improve the mother in caring for babies with low birth weight so as to minimize mortality and morbidity in infants.

\section{REFERENCES}

(1) Dinas Kesehatan Provinsi Jawa Tengah. Profil Kesehatan Jawa Tengah 2015. Semarang; 2015.

(2) Im H, Kim E. Effect of Yakson and Gentle Human Touch versus usual care on urine stress hormones and behaviors in preterm infants: A quasi-experimental study. International Journal of Nursing Studies. 2009;46(4):450-8.

(3) Flacking R, Lehtonen L, Thomson G, Axelin A, Ahlqvist S, Moran VH, et al. Closeness and separation in neonatal intensive care. Acta Paediatrica. 2012;101(10):1032-7. 
(4) Brett J, Staniszewska S, Newburn M, Jones $\mathrm{N}$, Taylor L. A systematic mapping review of effective interventions for communicating with, supporting and providing information to parents of preterm infants. BMJ open. 2011:bmjopen-2010-000023.

(5) Nicolaou M, Rosewell R, Marlow N, Glazebrook C. Mothers' experiences of interacting with their premature infants. Journal of Reproductive and infant Psychology. 2009;27(2):182-94.

(6) Ikatan Dokter Anak Indonesia. Konsensus: Asuhan Nutrisi pada Bayi Prematur. Jakarrta: Ikatan Dokter Anak Indonesia; 2016.

(7) Field T, Diego M, Hernandez-Reif M. Massage therapy research. Developmental Review. 2007;27(1):75-89.

(8) Kumar J, UpadhyayA, DwivediAK, Gothwal S, Jaiswal V, Aggarwal S. Effect of oil massage on growth in preterm neonates less than $1800 \mathrm{~g}$ : a randomized control trial. The Indian Journal of Pediatrics. 2013;80(6):465-9.

(9) Sankaranarayanan K, Mondkar J, Chauhan M, Mascarenhas B, Mainkar A, Salvi R. Oil massage in neonates: an open randomized controlled study of coconut versus mineral oil. Indian pediatrics. 2005;42(9):877.

(10)Fallah R, Karbasi SA, Golestan M, Fromandi M. Sunflower oil versus no oil moderate pressure massage leads to greater increases in weight in preterm neonates who are low birth weight. Early human development. 2013;89(9):769-72.

(11)Rangey PS, Sheth M. Comparative effect of massage therapy versus kangaroo mother care on body weight and length of hospital stay in low birth weight preterm infants. International journal of pediatrics. 2014;2014.

(12)Cho E-S, Kim S-J, Kwon MS, Cho H, Kim $\mathrm{EH}$, Jun EM, et al. The Effects of Kangaroo Care in the Neonatal Intensive Care Unit on the Physiological Functions of Preterm Infants, Maternal-Infant Attachment, and Maternal Stress. Journal of pediatric nursing. 2016;31(4):430-8.

(13)White-Traut RC, Rankin KM, Yoder JC, Liu L, Vasa R, Geraldo V, et al. Influence of H-HOPE intervention for premature infants on growth, feeding progression and length of stay during initial hospitalization. Journal of Perinatology. 2015;35(8):636.

(14)Sutarmi K, Melyana Nurul W. Love Touch Series 2: Pediatric Massage Therapy. Semarang: Indonesian Holisctic Care Association (IHCA); 2014.

(15) Saeidi R, Ghorbani Z, Shapouri Ma. The effect of massage with medium-chain triglyceride oil on weight gain in premature neonates. 2015.

(16)W.F G. Fisiologi Kedokteran (Review Of Medical Physiology) (22nd Ed.). Jakarta: Egc; 2012 